\title{
Liturgical music: Worship or war?
}

Elsabe Kloppers

Pretoria

\begin{abstract}
The way we are affected by music in general and the role of association, as well as the way association influences the forming of criteria for the evaluation of music and how these criteria would apply to church music, are discussed. The essence of liturgy and the function of music, as part of the liturgy are established. The conclusion is made that 'variety' is the key for the renewal of liturgical singing.
\end{abstract}

\section{THE CHURCH MOUSE}

Letter: Dear Church Mouse: Why can't Lutherans sing Christmas Carols during Advent?

Sincerely,

The Searcher

Response: Dear Searcher: I just don't know for sure. But let me tell you a little story regarding what happened in the church whose bell tower is my secret home.

'Twas the season before Christmas;

Thanksgiving prayers had been done;

Christ the King Sunday was past,

when the Church Mouse went for a run.

'Twas a sacristy conference in whispers

that drew my curious muridae ear.

Through the heating vent $I$ could see grins

while the pastors donned their liturgical gear.

* This article was an address delivered at the Ecumenical Insitute in Collegeville, Minnesota, on December 8, 1994. This essay is a reworked version published by Dialog Inc., 22481 Como Avenue, St Paul, Minnesota 55108, United States of America. Copyright ${ }^{\circ} 1995$ Dialog. Reprinted with permission. 
"We must hold the line against Christmas carols!

Snuff 'em out!" Pastor Hochaltar said,

"'Tis a war between Christ ' $n$ ' culture.

So let's give 'em Advent hymns instead."

"The secular world's invading the church!

The Christmas Spirit's just paltry sentiment.

So, we'll limit Christmas to twelve days

following four weeks that mimic lent".

Into the chancel of an empty church the pastors

stepped.

Then from the parking lot they heard a loud

clatter.

They paused, then raced to the windows and doors.

listening and looking to see what was the matter.

Arrayed before them in mass, they beheld,

hundreds of lay persons gathered in throngs

with pickets and signs and posters and chants

all demanding permission to sing Christmas songs.

On the church's big front door made of wood they found a long petition affixed, nailed.

'Twas a lengthy list of singable Christmas tunes.

"Note the number it's - 95!" - the laypeople hailed.

"No! No! No! Thrice times no!"

bellowed Pastor Hochaltar holding his ground.

"No Advent worship will be profaned here.

We're liturgically correct and theologically sound".

"By what authority do you douse the Christmas

Spirit?"

demanded the voices of the assembled society.

"Why do you dampen the joy of the hoi polloi?

Why do you throw a wet blanket on our piety"?

"The message of Christmas is proclaimed in the media.

And it's a message all the world should hear:

how God incarnate in Christ brings salvation.

'Tis the best mission opportunity of the year". 
With a face showing rage and judgment lacking age,

Pastor Hochaltar turned and stomped inside.

Back in a flash he stepped on the porch, and braced himself to hold back the tide.

He held framed certificates, one in each hand.

"This is my ordination lifted in the right.

My seminary graduation I raise in the left.

Both weapons in a holy war. I'm ready to fight".

"We're not, said the picketers, lowering their signs.

They turned to march away, one and all.

Last heard they were singing "Silent Night".

Where? At the Emporium Shopping Mall.

Sincerely,

The Church Mouse

\section{INTRODUCTION}

The amusing answer of the Church Mouse to the question why Lutherans may not sing Christmans carols, in Dialog (33/3 [Summer 1994] 165), illustrates well some of the reasons for war in the field of church music. In this case, at least, the pastor is the villain and not (as usual) the church organist - who might have been depicted as fighting the people off with an organ pipe! The kinds of arguments of the people and of the pastor (the piety of the people, the 'joy of the hoi polli', the opportunity for mission versus liturgical correctness, and so forth) show that the arguments for or against certain kinds of church music are often confused and not clear-cut. People might say they are not musically educated, or that they are not interested in theology - that they want merely to sing what they like and what they feel would express their faith well. What they do not seem to realize is that 'what I or we like' encompasses a world of cultural formation and that 'what expresses my faith well' refers to a world of theological thinking.

We all come from differing backgrounds and our points of view often differ considerably. In such a pluralistic situation almost everything becomes so relative that it is extremely difficult to draw any general guidelines especially regarding such a sensitive topic as church music. I realize that I cannot present principles that are valid for all people at all times and in all places, but in this minefield of relativity, I will try and find a line of thought that might serve as a guideline, if nothing more, for churches other than my own as well. 
I will go about it this way: First, I will discuss the way we are affected by music in general and the important role of association in this regard, as well as how association influences the forming of criteria for the evaluation of music. Secondly, I will show how these criteria apply to church music although they are not 'objectively' valid. I will then try to establish what the worship service is about - what its essence is, so that the function of music as part of the liturgy can be established. My discussion will be limited to liturgical singing, not only for reasons of space, but also because I believe singing to be the primary form of liturgical music. I will conclude by showing how variety can be the key for the renewal of liturgical singing.

\section{MUSIC AND ASSOCIATION}

In his essay Image Processes, Connotations, and Moods (1956), Leonard Meyer illustrates well that music does not mean anything in itself - that there is no causal relation between what is heard and that to which a sound is associated. He argues also that there is no definite or one to one correlation between association with the sound and the affect (the feeling) that will be brought about by this association. The personal affective experiences brought about by certain kinds of music often have nothing to do with the music as such, but are brought about by private image processes that are conscious or unconscious (Meyer 1956:257). A hymn might therefore have a certain effect on a person simply because of the personal memories brought about by that hymn memories the person might be aware of or unconscious ones. The specific experience of an individual may cause a 'happy' tune to be associated with images of a sad occasion - the real stimulus for the musical affective experiences being thus not 'the progressive unfolding of the musical structure, but the subjective content of the listener's own mind' (Meyer 1956:258).

If it is only about the 'subjective content' of the listener's mind, the question arises whether there are then any objective aesthetic criteria whereby music can be judged. A distinction must be made between the personal images and those formed by a certain group, although they might often overlap. Aesthetic criteria for judgments regardingmusic are indeed subject-related, meaning not a mere individual subjectivity, but that criteria are determined by a certain group, cultural or other, that is founded on convention and consensus. In the establishing of these values, association plays a major role.

Music cannot per se be humorous, happy, or sad, but through the repetitive use of certain musical expressions, we come to associate certain meaning with it. In the musical practice of the West, dotted notes played or sung fast, are so often used to depict humor, as in Scherzos for example, that such kinds of rhythms come to be associated with humor, joy, and frivolity: (The Humoresque of Dvorak is a example). 
Judgments based on association are also related to a specific time and place, such as the elaborate system of connotations which the composers of the Baroque period developed. This kind of system is understood by the people in a specific time and not necessarily by later generations. But this also does not mean that later generations are necessarily excluded from understanding the specific musical communication system as the lovers of Bach's music can testify. I argue this point in order to show that the communicative value of 'old' or 'traditional' church music need not be outdated or invalid just because of its age, but by way of association it can speak just as vividly and immediately as it did to its first hearers.

Certain associations are entirely traditional, such as when certain musical instruments become associated with special concepts and states of mind. The organ is associated for listeners in Western culture with the church, and through this with piety and - religious beliefs. As a rule associations are also used in combination so that each reinforces the other. If the composer wishes to evoke associations with religious beliefs, he will not only employ the appropriate instrument but he will also use techniques of composition that have the same associations.

The kind of music is also determined by association. In this way one can say that a piece of music has the character of a waltz, a march, or a song of grief. It is important to note that such kinds of connotations can only be made within a certain culture. Oriental music, African music, and music in Western culture not only differ from one another, but the associations brought about by the music differ, depending on the cultural group one belongs to. Associative judgments are thus determined by the cultural group. This is further strongly connected with levels of education, musical education, perception, as well as psychological and sociological determinants.

People (musicians) who have a thorough knowledge of music and broad exposure to various genres and styles are simply in a better position to make judgments of value and therefore their criteria for judgment, although not 'absolutely' objective, can and must be regarded as scientific.

People whose musical frame of reference is restricted must be careful not to make judgments of an adept group as unscientific, just because they themselves, through lack of knowledge, do not make the same associations. To illustrate this point: A group of church musicians can make associative judgments by way of comparison - because of their knowledge of a variety of musical styles and of church music specifically - and so can with fair certainty determine whether a certain melody is appropriate for a given text or not. They can, for instance, show that it would be inappropriate to use many dotted rhythms and upward leaps with a text that refers to the suffering of Christ, or the sin of the people. A person who knows only music with many dotted rhythms and other strong rhythmic characteristics will yet not be able to make such a distinction. 


\section{CRITERIA FOR CHURCH MUSIC: ABSOLUTELY OBJECTIVE?}

It is important to note that there is no difference between criteria for aesthetic judgments regarding church music and those for 'secular' music. In all cases criteria are determined by specific (adept) groups. Church music, unlike 'art music' in general, is music with a specific function and therefore its value is determined in terms of the function the music must fulfill in the liturgy. Criteria are narrowed in terms of this function, and both function and criteria are determined by a group, being in this case theologians and musicians of a specific church or denomination. The view of the musician usually stretches over denominational lines to correspond with the views of the (as I said) adept cultural group. The view about the function of music in the liturgy is codetermined by a person's view of scripture, confessional foundation, view of the church and view of the worship service. These are the reasons for wars - why views about appropriate music might differ considerably and why people can even differ about whether a hymn is a hymn.

The criteria for church music can thus never be objectively valid for everybody at all times and in all places. Does this imply a relativism which might allow everybody to sing just what every person would like to sing? No, then everybody would take turns to sing his or her individual solo in church.

\section{THE CHARACTER OF THE WORSHIP SERVICE OR LITURGY}

Immediately when I speak about solos, we all realize that that is not what the worship service is about. If the worship service is primarily about the faith of the individual believer, then why do we come together as a community? We come together to worship and to experience and express our faith as a believing community:

Saying that, I have also touched upon the essence of the worship service - that it is primarily about faith in God - about the total person (as part of the community) meeting the totally Other and being changed by this encoutner. Because of the totality of the person, not only the rational thoughts of the mind must be recognized, but also a person's experience of faith. The over-emphasis of either the ratio or personal experience has led to various kinds of liturgical distortions. In some denominations personal experience is so excessively emphasized as a criterion for authenticity of faith that the formative power of strong liturgy, and through that, the collective experience of faith, has been almost totally ignored. On the other hand, where only knowledge of the conscious mind is valid, it has happened that certain rational elements of the liturgy have been overemphasized to the expense of the other elements.

What happened in the first example had the consequence that music has been used merely to evoke personal feelings of piety. Music does not form an integral part of a 
meaningful and close-knit liturgy where the music is intrinsically bound up with the Word of God. In the second case, where personal experience has been almost completely avoided, and where the Word of God was seen exclusively as the spoken word - thus the sermon - the music has become almost mere 'markers' for other (spoken) liturgical acts. In both these cases the true liturgical function of the music as carrier, depicter, communicator of the essence of the worship service - as musical 'word' that wants to express or bring about the encounter with God - has been ignored.

These cases of one-sidedness today have the consequence that there is an urge for renewal of liturgical music. Unfortunately music is made the scapegoat for everything that is wrong with liturgy. Where liturgical elements have lost their meaning, or where the meaning has become unknown to the people, new music has to set everything right. Where the planning of the liturgy in order to form a meaningful, integrated whole is neglected, 'popular' music must disguise it. But before the music can thus be renewed, the liturgy must be renewed and made more meaningful. Every liturgical element should receive full attention and be meaningfully integrated with every other. Music can be the golden thread that binds the liturgical elements together, provided that every piece of music is chosen with the utmost care and attention.

\section{THE FUNCTION OF LITURGICAL SINGING}

Through its extraordinary range of symbols, liturgy as such has the power to shape experiences that make God's presence accessible, but it is especially through the powerful symbols of music that the encounter with an elusive God can be experienced. The community can yet also sing because of the encounter with the living God. Liturgical singing can thus bring the experience of faith about, or function as the expression of the experience of faith.

As I have already indicated, musical sounds are not explicit in their denotation and therefore cannot particularize the connotations which they arouse. In the liturgy this flexibility of connotation becomes a virtue, for it enables music to express what might be called 'the disembodied essence of myth, the essence of experiences which are central to and vital in human existence' (Meyer 1956 in Ostransky 1969:171).

Through these interassociations brought about by musical symbols, the undescribable, the ineffable can be communicated - thus that which we experience of God. The musical 'word' has in many ways better communicative possibilities than the spoken word. On the emotional level it can speak more intensely and with more subtlety. It can communicate affective dimensions and concepts that are impossible for the spoken word. Music can communicate with and through the total person and can therefore help to escape the pitfalls of one-sided rationalism in the liturgy. 
Liturgical singing can function as conversation with God, as answer to God's Word, that is, as praise, thanksgiving, confession, prayer, lament, and so forth. But liturgical singing can also function as God's Word - that is where the singing community can carry God's word out as mission toward the outside world or proclaim God's Word toward one another. Through this singing conversation of faith, the community can comfort one another, spur one another on to do what is expected of them, teach one another and even rebuke one another. In this way the community can be built up in faith. Hymns can thus have a didactic, kerygmatic, or other function.

The key for the renewal of liturgical music is the effective use of a variety of the above-named functions in a dynamic way. Although many hymns could in themselves fulfill a variety of functions because various verses might have differing points of focus, a big enough repertoire of hymns and songs for every separate function is necessary. Not only must there be enough hymns that praise God's glory, but there must also be enough hymns that express a defective believer's struggle with God and withhimself as a sinner. (Don't we perhaps prefer to sing praise hymns because we like to sing them and they make us feel good?)

A one-sided emphasis on any of these liturgical functions leads to a one-sided experience and expression of faith that does not provide for a plurality of believers in various stages of their lives and in differing states of mind. A one-sided emphasis, say, on the celebrative aspect, day after day, also brings about a diminished concept of faith, where it is assumed that faith means feeling good, being happy, successful, strong in trust. But, what about the other sides of faith?

Many of the wars surrounding liturgical music are primarily because of lack of knowledge of the function of liturgical elements and the musical expression of these elements, and because of one-sidedness and a tendency to absolutize views. Let me illustrate this point.

Young people often say: we dont want to sing that old stuff. It makes us feel depressed. We want to praise the Lord. We want to feel good. That is one-sided. They still lack the knowledge that faith — and life! — have different sides. Later they might come to know the other sides of life and then might find something lacking in the means to express their faith, or worse, might find that something is lacking in their faith (I am not as successful; my trust is not as deep; I am the only one who experiences doubt!), because they were exposed only to one side. One must never tire of explaining the full function of the liturgy and of liturgical music - and why all the functions cannot be fulfilled by one kind of music. 
A tendency to one-sidedness we have on the other hand is with people who believe that everything old is good - those people who are in favor of restoration per se. This applies especially to Genevan song and Gregorian chant. The problem usually is not having these sung, but that they want everything to be restored to the original form to what they believe to be the original form! With the Genevan song it is still more or less easy to find the 'original', because it existed as a corpus, but with Gregorian chant it is very difficult. The 'restorationists' therefore usually present the oldest known form of the chants as the ideal. From an historian's point of view, this is correct. Biblical scholars, preachers and so forth, also have to work with the oldest known (which usually are regarded as the most original) form of biblical writings. But, and this is the difference, they do not read the original Greek, Hebrew, or Aramaic in the liturgy simply because it is original.

Since music (Gregorian chant and Genevan song included) is much more understandable to us than these languages it is not a perfect comparison. What I am saying is that we can sing, and I believe should sing, this music but it will be more acceptable to people who are not as familiar with this music (and this includes most of the chuchgoers today) if smaller adaptations could be made in the structure of the melodic line to cut out leaps that are illogical to modern ears and difficult for modern tongues.

Another kind of one-sidedness we find is with people who do not want to sing 'old' music, or 'new' music, for that matter, but only that which they already know those songs that are in their memory, and are usually what they sang at summer camp. Unfortunately, what was usually sung at summer camp seems often to be those songs that were historically not included in 'official' hymnbooks because of their theological or musical one-sidedness and, let me dare say it, even questionability, as well as poetic poverty. Many of these well-known songs are now included in new 'official' hymnals, but often with words slightly changed to make them theologically and poetically more acceptable. But still people are not satisfied. 'These are not the songs we remember', they lament. Gracia Grindal, who was responsible for some of the new texts of these beloved old songs, made the interesting and amusing remark in a personal conversation that whenever you change a text, just don't change the first verse, and especially, not the first line. What she means is that that is actually all the people remember and in changing that, the whole song is discredited.

All these cases of one-sidedness that spark wars are mostly related to the fact that the function of music in the liturgy is not sufficiently borne in mind. The text and the music of a hymn stand in direct relation to the function the hymn must fulfill in the liturgy. It is easy to say: the general person is not interested in theological correctness in hymns, nor do they want to know what 'good' music is - my examples in the beginning. It will really be confusing when the theology of a hymn contradicts the theology of the sermon or the rest of the liturgy. It will thus contradict its function as an 
integrating part or the unity of the liturgy. If associations are brought about by the music that oppose what is meant to be communicated by the words of the text and the rest of the liturgy, then the music loses its possibility as the generic event, as the symbol that has the possibility to integrate and bind the liturgy as a whole.

What are the requirements then, musical and textual, that have to be met so thatsinging can appropriately fulfill this function in the liturgy? I will first focus on the textual requirements.

\section{TEXTS OF LITURGICAL SONGS}

A person's view of what an appropriate text must be and how it must function will correspond with his or her view of scripture and how it should be applied in today's circumstances. If people have a fundamentalistic view of scripture, they might have specific views on what in the Bible would be appropriate to sing and what not. They might have the idea, for example, that only Psalms are appropriate to sing because they are already songs, and therefore songs given directly by God and without human words mixed in. These people tend to forget that they sing the Psalms in translated and/or strophic form (therefore adapted) and that any translation is already interpretation. Another fundamentalistic view is that the words of the Bible must only be sung literally, because it is the way God has given his Word (that is also impossible in a translation).

A form of fundamentalism related to this I found in the book Why Catholics Can't Sing, by Thomas Day, where he refers to the large number of new hymns in the first person, that directly echo God's words. He lists almost thirty titles, among them titles such as: I am the bread of life; I am the resurrection; I, the Lord, and so forth. He sees this as a way for the singing community to play the role of God. Considering the specific functions music has to fulfill in the liturgy, his concern seems legitimate. What function could these I-hymns fulfill? When the community speaks to God, they cannot simply reflect God's words back to him. They can thus not fulfill a function in the God/community conversation. When the members of the community speak to one another, they have to relate what God says in the third person, and speak about themselves in the first person. 'I am a sinner; we have experienced God's grace; He urges us to ...' It is true that at a well-placed position in the liturgy such hymns can function as a kind of scripture reading, once in a while, but when these hymns are so multiple and commonly sung by the whole congregation, it is certainly a sign of one-sidedness and lack of knowledge of the function of liturgical music. 
The problem with texts quoting the Bible directly, but out of context, is that a false impression can be created. To use well-known and extreme examples, I could quote hair-raising abstracts from the revenge Psalms, but I would rather illustrate my point with a more subtle example from a beautiful Taizé-song that goes: Jesus, remember me when you come into your kingdom. These are the direct words of the criminal on the cross next to Jesus - so striking within its context - but in the mouths of today's believers, it can say that Jesus is not yet in his kingdom.

The same kind of work with the biblical text is required for the text of hymns as for the sermon. Here Gerhard Ebeling unavoidably comes to mind: he said that the same word of the text can only be said understandably for another time if it is said differently. The preacher does not simply repeat the biblical word, but interprets it and molds it into another form - he re-creates his own experience with the text into new, contemporary symbols, and in doing so, makes it understandable for the people of his own time so that they can come to as similar an experience of the text as the first hearers. The same exegetical, hermeneutical, and other theological principles apply for the writer of hymntexts as for the preacher - the text writer being yet more bound to poetic use of language, rhythm, and form, especially because music demands a more set form. Literary integrity, creativity, and expression play an important part in the writing of texts for hymns (if only they could play a bigger role in the sermon as well!)

'Textwriters', who simply repeat the literal biblical text, without unlocking it hermeneutically to place it appropriately in the mouth of the contemporary believer and who then often combine these texts with inappropriate music, are not worth the name of 'hymnwriters'. What strikes one is how fond these people are of copyright restrictions to protect their 'original creations'.

In sum, the following can be said about the texts of hymns: The language must be concise, images must be relevant, religious clichés and stereotypes in language must be avoided, and repetition must be meaningful - one can say the same broad principles about which there is consensus (note the word again) among literary critics on that which constitutes a good poem. Texts that form thematic unities and texts that are short enough to be sung as a whole can be most functional in the liturgy.

We must ask then what criteria apply for the music of the songs in the liturgy.

\section{MUSICAL CRITERIA FOR LITURGICAL SINGING}

What determines the music in the first place is the text. Apart from all the symbolic meaning and possibilities music has on its own, it should be structured by the text to avoid arbitrariness and to be functional in the liturgy. These are the reasons why I regard singing as the primary, although not the only, form of liturgical music. If a text 
is theologically clear and of good poetic value, then music can be written that fits the text. This does not necessarily mean that the text must always be written first - we know many examples of the opposite but it means that the music must be subordinate to the text in the sense that it must interpret, support, and carry the text. The music must keep in mind the natural flow of the words, the rhythm, stress, phrasing, pitch, as well as the meaning of the words. The character of the music must thus fit the character of the text. One cannot sing a confession of sin to the melody of a song of praise and so too one cannot simply put the music of any secular song, with its own world of connotations together with sacred words and say: now it is a hymn!

The criteria for the melodies are directly related to the function of the music in the liturgy. Unless music has a function that could be better fulfilled by choral singing, such as a kerygmatic function, it must be music for the whole congregation - therefore music that can be sung by a large, fairly untrained group. Here a large number of requirements apply that have been established by trained musicians through years of working with such groups. What these people say is often ignored and they are simply depicted as being difficult - the actual warmakers. Because of their experience, they can with fair certainty say when a piece of music will be too difficult, when there are illogical and difficult leaps, when the range is too wide, the key uncertain, or too many melismas for a middle class congregation to sing it with ease.

With regard to the said consensus within an adept group, they can also, together with fellow trained musicians, say when a piece of music is weak and will probably become boring after a short while, because it lacks strong movement, certain points of climax, has too many meaningless repetitions, sequences, dotted notes, and so forth. For well-trained musicians to say music is, for example, sentimental, emotionally superficial (schmaltzy?); is thus not just dependent on some vague feeling, but can in terms of their science be scientifically validated, just as the art critic can evaluate an artwork, a literary critic can evaluate a poem, and a theologian can evaluate a sermon. Still, as I have shown, such evaluations can never be absolutely valid and objective. Keeping criteria in mind can never guarantee a good hymn, poem, artwork, or sermon. But that does not mean that we must discard all criteria, just because they do not give absolute certainty, and then fall into a mere arbitrariness. The key word is balance. No element harmonic, melodic, or rhythmic - may become dominant at the expense of the others, and none of these elements may become so dominant that the text is overshadowed. 


\section{VARIETY: THE OPPORTUNITY FOR MEANINGFUL RENEWAL}

In order to be relevant in each time there certainly must be constant renewal in liturgical music. I have tried to draw certain parameters within which liturgical music can be renewed and to show that everything is not merely a matter of personal taste. I believe that the opportunity for meaningful renewal lies in variety - in the first place liturgical variety and secondly in the implementation of diverse musical idioms, styles, and forms with their liturgical function being constantly borne in mind. Such variety can present various possibilities for the diversity of people within a congregation and can expand the spectrum of the experience of faith for the different believers.

To have different liturgies with different kinds of music, for example, a liturgy with only traditional music for the people who are opposed to renewal, another liturgy with only rhythmical folk or pop music for young people, is counter-productive. In both cases the idea is established that only one kind of music is appropriate for the specific group, and so the contact with any other kind of liturgical music and its specific function is lost.

In the first case history can become stagnant, but in the second case the danger is even worse, because the young people who hear in 'their' liturgy only new, rhythmic music can lose the idea of any historical binding and continuity within the church and its history - a history within which the central message of the gospel is handed on, a gospel that is in its very essence historically grounded.

When a congregation sings only one kind of liturgical music - music that is often new as well - it also inevitably loosens its ecumenical ties. We know hymns and chants across the borders of denominations; the same songs can be the popular songs in various churches; we come to realize that our church's favorites are other churches' songs as well, and that we, through these hymns and chants, could experience and express our faith together. Through these songs of faith we could meet God and meet one another. I am furthermore convinced that these common hymns and chants are those that have passed the test and that can be used as examples for new collective songs through which our ecumenicity could be expressed.

Apart from all the human attempts and wars, in the end it is only the Holy Spirit who can make genuine communication of faith possible. It is only the Holy Spirit who can inspire creations that evoke faith and whereby faith can be expressed. Therefore we must constantly sing and pray: Veni, Creator Spiritus ...

\section{Works consulted}

Day, T 1991. Why Catholics Can't Sing: The Culture of Catholicism and the Triumph of Bad Taste. Crossroad: New York.

Meyer, L 1956. Image Processes, Connotations, and Moods, in Emotion and Meaning in Music. University of Chicago Press: Chicago. 